\title{
Pengaruh Model Pembelajaran Jigsaw Berbasis Penilaian Portofolio Terhadap Kompetensi Pengetahuan PKn
}

\author{
Ni Putu Reni Andayani ${ }^{1}$, I G A Agung Sri Asri ${ }^{2}$, Ni Wayan Suniasih ${ }^{3}$ \\ ${ }^{123}$ Jurusan Pendidikan Guru Sekolah Dasar \\ Universitas Pendidikan Ganesha \\ Singaraja, Indonesia \\ e-mail: niwayan.suniasih@gmail.com
}

\begin{abstract}
Abstrak
Penelitian ini bertujuan untuk mengetahui pengaruh model pembelajaran jigsaw berbasis penilaian portofolio terhadap kompetensi pengetahuan PKn siswa kelas IV SD Gugus Teuku Umar Denpasar Barat tahun pelajaran 2017/2018. Penelitian ini merupakan penelitian eksperimen semu dengan rancangan nonequivalent control group design. Populasi dalam penelitian ini sebanyak 239 siswa kelas IV SD Gugus Teuku Umar. Sampel penelitian ditentukan dengan teknik random sampling. Sedangkan sampel yang digunakan berjumlah 76 siswa yang terdiri dari siswa kelas IV SDN 13 Dauh Puri sebagai kelas eksperimen yang berjumlah 42 siswa dan SDN 12 Dauh Puri sebagai kelas kontrol yang berjumlah 34 siswa. Pengumpulan data dilakukan dengan metode tes dalam bentuk pilihan ganda biasa. Selanjutnya data dianalisis dengan uji-t. Hasil analisis menunjukkan bahwa terdapat perbedaan yang signifikan kompetensi pengetahuan PKn antara kelompok siswa yang dibelajarkan menggunakan model pembelajaran jigsaw berbasis penilaian portofolio dan siswa yang dibelajarkan menggunakan pembelajaran konvensional siswa kelas IV SD Gugus Teuku Umar Denpasar Barat tahun pelajaran 2017/2018. Dengan demikian dapat disimpulkan bahwa terdapat pengaruh model pembelajaran jigsaw berbasis penilaian portofolio terhadap kompetensi pengetahuan PKn siswa kelas IV SD Gugus Teuku Umar Denpasar Barat tahun pelajaran 2017/2018. Penelitian ini dapat dijadikan sebagai hasil kajian yang relevan bagi peneliti lain yang ingin mengkaji lebih dalam mengenai model pembelajaran jigsaw berbasis penilaian portofolio.
\end{abstract}

Kata Kunci: Model pembelajaran jigsaw, penilaian portofolio, kompetensi pengetahuan PKn

\begin{abstract}
The research airned to determine the influence of learning model jigsaw based assessment portfolio against competence knowledge civic education students of class IV elementary school Gugus Teuku Umar west Denpasar in the academic year 2017/2018. This research is a quasi-experimental research with nonequivalent control group design. The population in this research is all class IV elementary school Gugus Teuku Umar west Denpasar in tne academic years 2017/2018 as many 239 students. Research sampel is determined by random sampling technique. While the sample used in experiments that amounted to 76 students. The sample in this research is class IV elementary school 13 Dauh Puri as an experimental group of 42 students and SDN 12 Dauh Puri as a control group which amounted to 34 students. The Civic Education knowledge competence control data is collected with instrumens in the from of multiple choice test. Than the data is analyzed by $t$-test. The result of the analysis show that there is a significant difference of civic education knowledge competence among group of students who are tought using learning model jigsaw berbasis assessment portfolio and teach using learning conventional on the student class IV elementary school Gugus Teuku Umar west Denpasar academic year 2017/2018. Thus it can be concluded that there is the influence of jigsaw learning model based assessment portfolio of knowledge competence of class IV students of elementary school Gugus Teuku Umar West Denpasar in the academic year 2017/2018. Based on the results of research that the results of this study can be used as a result of relevant studies and deepen the theory, examine more deeply of learning model jigsaw based assessment portfolio.
\end{abstract}

Keywords: Jigsaw, assessment portfolio, civic education knowledge competence 


\section{Pendahuluan}

Pasal 1 UU SISDIKNAS no. 20 tahun 2003 disebutkan bahwa Sistem Pendidikan Nasional adalah keseluruhan komponen pendidikan yang saling terkait secara terpadu untuk mencapai tujuan pendidikan nasional. Berangkat dari bunyi pasal ini dapat diketahui bahwa pendidikan adalah sistem yang merupakan suatu totalitas struktur yang terdiri dari komponen yang saling terkait dan secara bersama menuju kepada tercapainya tujuan (Soetarno, 2003: 2). Adapun komponen-komponen dalam pendidikan nasional antara lain adalah lingkungan, saranaprasarana, sumberdaya, dan masyarakat. Komponen-komponen tersebut bekerja secara bersama-sama, saling terkait dan mendukung dalam mencapai tujuan pendidikan. Tujuan pendidikan nasional yang dirumuskan dalam UU SISDIKNAS adalah untuk mengembangkan potensi anak didik agar menjadi manusia yang beriman dan bertakwa kepada Tuhan Yang Maha Esa, berakhlak mulia, sehat, berilmu, cakap, kreatif, mandiri, dan menjadi warga Negara yang demokratis serta bertanggung jawab (Munirah, 2015).

Pendidikan merupakan sebuah sistem. Sebagai sistem, aktivitas pendidikan terbangun dalam beberapa komponen, yaitu pendidik, peserta didik, tujuan pendidikan, alat pendidikan, dan lingkungan pendidikan. Semua komponen yang membangun sistem pendidikan, saling berhubungan, saling tergantung, dan saling menentukan satu sama lain. Setiap komponen memiliki fungsi masing-masing dalam rangka mencapai tujuan pendidikan. Aktivitas pendidikan akan terselenggara dengan baik apabila didukung oleh komponen-komponen dimaksud. Fungsi pendidikan sebenarnya adalah menyediakan fasilitas yang dapat memungkinkan tugas pendidikan dapat berjalan lancar, baik secara struktural, maupun secara institusional. Secara struktural menuntut terwujudnya struktur organisasi yang mengatur jalannya proses kependidikan. Secara institusional mengandung implikasi bahwa proses kependidikan yang terjadi dalam struktur organisasi itu dilembagakan untuk lebih menjamin proses pendidikan itu berjalan secara konsisten dan berkesinambungan mengikuti kebutuhan dan perkembangan manusia yang cenderung ke arah tingkat kemampuan yang optimal (Saat, 2015).

Pendidikan sebagai bagian kehidupan masyarakat di era global harus dapat memfasilitasi bagi tumbuh dan berkembangnya keterampilan intelektual, sosial dan personal. Menurut UU. No. 20 tahun 2003 Pendidikan adalah usaha sadar dan terencana untuk mewujudkan suasana proses pembelajaran agar peserta didik secara aktif mengembangkan potensi dirinya untuk memiliki kekuatan spiritual, keagamaan, pengendalian diri, kepribadian, kecerdasan, akhlak mulia, serta keterampilan yang diperlukan dirinya, masyarakat, bangsa dan Negara. "Pendidikan adalah usaha sadar untuk menyiapkan peserta didik melalui kegiatan bimbingan, pengajaran, dan latihan bagi peranannya di masa mendatang" (Wahyudin, 2004:2.17). Sedangkan menurut Indah (2017) Pendidikan pada dasarnya adalah usaha sadar untuk menumbuhkan potensi sumber daya manusia peserta didik dengan cara mendorong dan memfasilitasi kegiatan belajar mereka. Dengan demikian pendidikan adalah bagian dari proses kehidupan bernegara untuk mewujudkan suasana pembelajaran agar siswa aktif dan mengembangkan potensi peserta didik dengan cara memfasilitasi kegiatan belajar mereka. Pendidikan harus menumbuhkan berbagai kompetensi peserta didik. Keterampilan intelektual, sosial dan personal dibangun tidak hanya dengan landasan logika saja, tetapi juga inspirasi, kreativitas, moral, emosi, dan spiritual. Sekolah sebagai institusi pendidikan dan miniatur masyarakat perlu mengembangkan pembelajaran sesuai tuntutan era global.

Sekolah dasar atau pendidikan dasar tidak semata-mata membekali anak didik berupa kemampuan membaca, menulis dan berhitung semata, tetapi harus mengembangkan potensi pada siswa baik potensi mental, sosial dan spiritual. "Sekolah dasar memiliki visi mengembangkan manusia yang beriman dan bertakwa kepada Tuhan Yang Maha Esa, berakhlak mulia, sehat, cakap, kreatif, mandiri, dan menjadi warga Negara yang demokratis dan bertanggung jawab" (Susanto,2013:70). Seiring dengan perkembangan ilmu pengetahuan dan teknologi, maka secara otomatis pola pikir masyarakat berkembang dalam setiap aspek. Hal ini sangat berpengaruh besar terutama dalam dunia pendidikan yang menuntut adanya inovasi baru yang dapat menimbulkan perubahan, secara kualitatif yang berbeda dengan sebelumnya.

Pada pelaksanaaan pendidikan perlu adanya suatu kurikulum yang dapat mendukung proses pendidikan yang baik. Kurikulum adalah suatu respon pendidikan terhadap kebutuhan masyarakat dan bangsa dalam membangun generasi muda bangsanya, di mana guru memegang peran utama dan bertanggung jawab meyebarluaskan gagasan baru, baik terhadap siswa maupun masyarakat melalui proses pengajaran dalam kelas. Dalam pelaksanaan pendidikan yg baik masih terdapat kendala-kendala yang dihadapi guru yakni dari hasil observasi kurang aktifnya siswa di kelas membuat siswa merasa bosan dalam pembelajaran dan jika 
dilaksanakannya pembentukan kelompok siswa hanya memilih kelompok yang disenangi sehingga siswa yang tidak terpilih sulit untuk bersosialisasi dan sulit untuk mengembangkan ilmu pengetahuan mereka. Hal ini juga terjadi pada mata pelajaran Pendidikan Kewarganegaraan (PKn)."PKn merupakan usaha untuk membekali peserta didik dengan pengetahuan dan kemampuan dasar berkenaan dengan hubungan antar warga Negara dengan Negara" (Sutoyo,2011:6) . Winataputra (2014:1.15) Mata pelajaran pendidikan kewarganegaraan merupakan mata pelajaran yang memfokuskan pada pembentukan warga Negara yang memahami dan mampu melaksanakan hak-hak dan kewajibannya untuk menjadi warga Negara Indonesia yang cerdas, terampil dan berkarakter yang diamanatkan oleh Pancasila dan UUD 1945. Sedangkan Susanto (2013:225) Pendidikan Kewarganegaraan adalah mata pelajaran yang digunakan sebagai wahana untuk mengembangkan dan melestarikan nilai luhur dan moral yang berakar pada budaya bangsa Indonesia. Dari pendapat tersebut dapat disimpulkan PKn adalah mata pelajaran untuk membekali dan membentuk peserta didik agar mampu menerapkan hak-hak dan kewajibannya sebagai warga Negara. Salah satu upaya mengatasi permasalahan ini, guru harus mampu merancang model pembelajaran yang bermakna bagi siswa. Untuk itu, guru harus kreatif dalam mendesain model pembelajaran yang memungkinkan siswa dapat berpartisipasi, aktif, dan kreatif terhadap materi yang diajarkan.

Model Pembelajaran adalah suatu perencanaan atau suatu pola yang digunakan sebagai pedoman dalam merencanakan pembelajaran di kelas. (Shoimin, 2014:23) Model pembelajaran adalah kerangka konseptual yang melukiskan prosedur yang sistematis dalam mengorganisasikan pengalaman belajar untuk mencapai tujuan belajar tertentu. Sedangkan Kurniasih (2017:18) Model pembelajaran merupakan sebuah prosedur yang sistematis dalam mengorganisasikan pengalaman belajar untuk mencapai tujuan belajar. Dengan demikian model pembelajaran berarti acuan pembelajaran yang dilaksanakan berdasarkan pola-pola pembelajaran secara sistematis. Bahwa setiap model pembelajaran mengarahkan pendidik ke dalam mendesain pembelajaran untuk membantu peserta didik sedemikian rupa sehingga tujuan pembelajaran tercapai. Pembelajaran yang bernaung dalam teori kontruktivis adalah kooperatif.

Model pembelajaran kooperatif tipe jigsaw (I) pertama kali dikembangkan oleh Aronson dkk (1978). Kemudian Slavin (1990) mengembangkan tipe jigsaw II sebagai koreksi atas model pembelajaran kooperatif tipe jigsaw I yang dikembangkan oleh Aronson dkk tersebut. Pada tahap selanjutnya Slavin (1990) mengembangkan tipe jigsaw III dalam konteks kelas bilingual. Kelebihan model pembelajaran kooperatif tipe jigsaw yang secara umum diakui para guru adalah bahwa proses pembelajaran dilakukan secara terstruktur dan prosedural, sedemikian sehingga setiap anggota kelompok ditantang dan dirangsang untuk secara aktif merespon persoalan yang harus mereka kuasai dan selesaikan. Prosedur pada model pembelajaran kooperatif tipe jigsaw I mengandung kelemahan cenderung membuat setiap anggota kelompok hanya terfokus pada satu persoalan yang menjadi tanggungjawabnya, karena tidak ada prosedur yang menantang setiap anggota untuk menguasai seluruh persoalan (Adimassana, 2016).

Diungkapkan Lie (1993:73), bahwa pembelajaran model kooperatif Jigsaw ini merupakan model belajar kooperatif dengan cara siswa belajar dalam kelompok kecil yang terdiri atas empat sampai enam orang secara heterogen, dan siswa bekerjasama, saling ketergantungan positif dan bertanggung jawab secara mandiri. Menurutnya Rusman (2008) model pembelajaran jigsaw adalah pembelajaran yang dilakukan dengan mendorong peserta didik untuk mengemukaan pendapat dan mengelola informasi sehingga siswa secara langsung mampu untuk meningkatkan keterampilan berkomunikasi dari materi yang telah dipelajari. Sudrajat (2008) Memberikan pengertian bahwa tipe pembelajaran kooperatif jigsaw adalah pembelajaran yang dilakukan dengan berkelompok dan mampu mengajarkan materi tersebut kepada kelompok lainya (Suprihatin, 2017).

Pembelajaran kooperatif muncul dari konsep bahwa siswa akan lebih mudah menemukan dan memahami konsep yang sulit jika peserta didik saling berdiskusi dengan temannya. Dalam Pembelajaran kooperatif ini, guru berperan sebagai fasilitator sebagai jembatan penghubung kearah pemahaman yang lebih tinggi, dengan catatan siswa sendiri. Pembelajaran kooperatif disusun dalam sebuah usaha untuk meningkatkan partisipasi siswa, memfasilitasi siswa dengan pengalaman sikap kepemimpinan dan membuat keputusan dalam kelompok, serta memberikan kesempatan pada siswa untuk berinteraksi dan belajar bersama-sama siswa yang berbeda latar belakangnya. Jadi dalam pembelajaran kooperatif siswa berperan ganda sebagai siswa ataupun sebagai guru. Dengan bekerja secara kolaboratif utuk mencapai tujuan bersama maka siswa akan mengembangkan keterampilan berhubungan dengan sesama manusia yang akan sangat bermanfaat bagi kehidupan diluar sekolah. Model Pembelajaran kooperatif memungkinkan 
semua peserta didik dapat menguasai materi pada tingkat penguasaan yang relatif sama atau sejajar.

Cooperatif learning atau pembelajaran kooperatif dapat mengembangkan pemahaman siswa tentang isi materi, memahami konsep-konsep serta mendorong siswa aktif, partisipatif, dalam pembelajaran. Model Pembelajaran kooperatif terdiri atas beberapa tipe. Salah satunya adalah tipe jigsaw. Tipe jigsaw adalah model pembelajaran kooperatif dimana pembelajaran melalui penggunaan kelompok kecil siswa yang bekerja sama dalam memaksimalkan kondisi belajar untuk mencapai tujuan pembelajaran dan mendapatkan pengalaman belajar yang maksimal, baik pengalaman individu maupun pengalaman kelompok. "Siswa tidak hanya mempelajari materi yang diberikan, tetapi juga harus siap memberikan dan mengajarkan materi tersebut kepada kelompoknya" (Budiyanto,2016:79). Pada pembelajaran tipe jigsaw ini setiap siswa menjadi anggota dari 2 kelompok, yaitu anggota kelompok asal dan anggota kelompok ahli. Anggota kelompok asal terdiri dari 4-6 siswa yang setiap anggotanya diberi nomor dada 1 6.

Selain menggunakan model jigsaw perlunya upaya untuk mengintegrasikan kegiatan pengukuran kompetensi pengetahuan siswa dengan keseluruhan proses pembelajaran dengan menggunakan penilaian portofolio.

Trianto (2007:277) menyatakan, penilaian portofolio adalah pengukuran sejauh mana kemampuan siswa dalam mengkonstruksi dan merefleksi suatu pekerjaan/tugas/karya dengan mengoleksi atau mengumpulkan bahan yang relevan dengan tujuan dan keinginan yang dikonstruksi oleh siswa kemudian pada akhirnya dapat membantu siswa menjadi sadar untuk meningkatkan dirinya sebagai pembaca dan penulis yang baik.

Hal ini bertujuan agar guru bisa mendokumentasikan dan menilai hasil pekerjaan siswa sehingga bisa memantau kemajuan siswa dari hari ke hari dan mendorong siswa merefleksi pembelajaran mereka sendiri, dengan demikian siswa bisa memperbaiki hasil pekerjaannya. Untuk itu dilakukan penelitian yang berjudul "Pengaruh Model Pembelajaran Jigsaw Berbasis Penilaian Portofolio Terhadap Kompetensi Pengetahuan PKn Siswa Kelas IV SD Gugus Teuku Umar Denpasar Barat Tahun Pelajaran 2017/2018".

\section{Metode}

Penelitian ini dilaksanakan di SD Gugus Teuku Umar Denpasar Barat. Lokasi ini dipilih karena memiliki aspek pendukung agar penelitian dapat berjalan dengan baik. Adapun aspek pendukung tersebut antara lain adalah seluruh SD di Gugus Teuku Umar secara serentak sudah menerapkan kurikulum 2013, lokasi sekolah dalam 1 Gugus yang cukup berdekatan sehingga lebih memudahkan dalam melaksanakan penelitian, dan juga tidak terdapatnya kelas unggulan di setiap sekolah dalam Gugus tersebut. Sekolah yang dijadikan sebagai penelitian kelompok eksperimen dan kelompok kontrol yaitu SDN 13 Dauh Puri pada kelas IV sebagai kelompok eksperimen dan SDN 12 Dauh Puri pada kelas IVsebagai kelompok kontrol. Adapun waktu penelitian ini dilaksanakan pada bulan Desember 2017 sampai dengan bulan Mei 2018. Kegiatan yang dilakukan selama penelitian dimulai dari pengajuan judul proposal, revisi judul, penyusunan proposal, bimbingan proposal, seminar proposal, revisi proposal, persiapan penelitian, pengumpulad data, analisis data, penyusunan skripsi dan ujian skripsi. Pelaksanaan penelitian pada masing-masing sampel penelitian dilaksanakan pada bulan April 2018.

Jenis rancangan penelitian yang dilakukan di penelitian ini adalah penelitian kuantitatif dengan desain eksperimen semu atau quasi eksperimen. "Desain ini memiliki kelompok kontrol, tetapi tidak dapat berfungsi sepenuhnya untuk mengontrol variabel-variabel luar yang mempengaruhi pelaksanaan eksperimen" (Sugiyono,2011:114). Sedangkan menurut Setyosari (2016:49) dalam penelitian eksperimen semu tidak memilih secara random untuk menetapkan subjek yang dilibatkan dalam perlakuan, dalam hal ini harus menggunakan kelompok atau kelas kelas yang telah tersedia. Hal ini dikarenakan kemampuan dalam mengamati prilaku siswa sangat terbatas terutama saat siswa berada di luar sekolah. Dari pendapat tersebut disimpulkan bahwa eksperimen semu memilih secara random kelompok kontrol tetapi hanya menggunakan kelompok atau kelas kelas yang telah tersedia. Penelitian ini dilaksanakan pada semester 2 tahun pelajaran 2017/2018 di kelas IV SD Gugus Teku Umar Denpasar Barat. Penelitian ini bertujuan untuk mengetahui perbedaan kompetensi pengetahuan PKn antara kelompok siswa yang dibelajarkan dengan model pembelajaran jigsaw berbasis portofolio dengan kelompok siswa yang dibelajarkan dengan pembelajaran konvensional. Rancangan eksperimen yang digunakan adalah nonequivalent Control Group Design. Pre-test diberikan untuk kelompok kontrol dan kelompok eksperimen untuk mengetahui kompetensi pengetahuan sebelum diberi 
perlakuan. Setelah memberikan pre-test peneliti memberikan perlakuan, yaitu dengan memberikan model pembelajaran jigsaw berbasis penilaian portofolio kepada kelas eksperimen dan pembelajaran konvensional pada kelompok kontrol selanjutnya dilakukan post-test untuk mengetahui kompetensi pengetahuan PKn setelah diberi perlakuan. Berdasarkan hal tersebut, maka dalam penelitian ini pre tes digunakan untuk menyetarakan kelompok. Teknik yang digunakan dalam penyetaraan kelompok adalah dengan menggunakan uji t.

Dalam penelitian ini untuk menentukan subjek penelitian langkah awal dalam penelitian ini adalah menetukan populasi yang akan diteliti. "Populasi diartikan sebagai wilayah generalisasi yang terdiri atas: obyek/subyek yang mempunyai kualitas dan karakteristik tertentu yang ditetapkan oleh peneliti untuk dipelajari dan kemudian ditarik kesimpulannya" (Sugiyono,2011:297). Menurut Setyosari, (2016:221) Populasi merupakan keseluruhan dari objek, orang, peristiwa, atau sejenisnya yang menjadi perhatian dan kajian dalam penelitian. Menurut Agung (2014:69) Populasi adalah keseluruhan objek dalam suatu penelitian. Jadi dari pendapat tersebut disimpulkan bahwa populasi adalah keseluruhan objek atau subjek yang mempunyai kualitas dan karakteristik yang menjadi perhatian dan kajian dalam penelitian untuk dipelajari dan kemudian ditarik kesimpulannya. Populasi dalam penelitian ini adalah siswa kelas IV SD Gugus Teuku Umar Kecamatan Denpasar Barat tahun pelajaran 2017/2018 dengan 6 kelas yang berjumlah 239 siswa.

Setelah mengetahui populasi selanjutnya menetapkan sampel yang digunakan dalam penelitian. Menurut Sugiono (2011:118) sampel adalah bagian dari jumlah dan karakteristik yang dimiliki oleh populasi tersebut. Bila populasi besar, dan penelitian tidak mungkin mempelajari semua yang ada pada populasi, misalnya karena keterbatasan dana, tenaga dan waktu, maka peneliti dapat menggunakan sampel yang diambil dari populasi itu. Apa yang dipelajari dari sampel itu, kesimpulannya akan dapat diberlakukan untuk populasi. Untuk itu sampel yang diambil dari populasi harus betul betul representative (mewakili). Menurt Setyosari (2016:220) Sampel adalah "sekelompok objek, orang, peristiwa, dan sebagainya yang merupakan representasi dari keseluruhan". Menurut Agung (2014:69) Sampel ialah sebagian dari populasi yang diambil, yang dianggap mewakili seluruh populasi dan diambil menggunakan teknik tertentu. Jadi berdasarkan pendapat diatas dapat disimpulkan bahwa sampel adalah perwakilan yang dimiliki populasi untuk digunakan dalam penelitian yang dilakukan.

Berdasarkan karakteristik populasi tidak bisa dilakukan pengacakan individu, maka pengambilan sampel pada penelitian ini dilakukan dengan acak atau random sehingga semua populasi memiliki hak yang sama untuk dijadikan sampel. Setelah melakukan teknik random sampling dilakukan uji kesetaraan terlebih dahulu sehingga dapat ditetapkanlah kelas IV SDN 13 Dauh Puri yang berjumlah 42 siswa sebagai kelompok eksperimen dan kelas IV SDN 12 Dauh Puri yang berjumlah 34 siswa untuk kelompok kontrol. "Variabel Penelitian merupakan faktorfaktor yang berperan dalam peristiwa atau gejala yang akan diteliti" (Setyosari 2015:163). Penelitian ini menyelidiki pengaruh variabel bebas dalam penelitian ini yakni model pembelajaran Jigsaw berbasis penilaian portofolio terhadap variabel terikat dalam penelitian ini yakni kompetensi pengetahuan PKn.

Data yang diperlukan adalah data tentang Kompetensi Pengetahuan PKn siswa kelas IV SD Gugus Teuku Umar. Untuk mengumpulkan data Kompetensi Pengetahuan tersebut digunakan metode tes. "Tes merupakan suatu teknik atau cara yang digunakan dalam rangka melaksanakan kegiatan pengukuran, yang di dalamnya terdapat berbagai pertanyaan, pernyataan, atau serangkaian tugas yang harus dikerjakan atau dijawab oleh peserta didik untuk mengukur aspek prilaku peserta didik" (Arifin,2009:118). Sedangkan menurut Suharsimi (2016:67) Tes adalah merupakan alat atau prosedur yang digunakan untuk mengetahui atau mengukur sesuatu dalam suasana, dengan cara dan aturan-aturan yang sudah ditentukan. Metode tes digunakan untuk memperoleh data tentang kompetensi pengetahuan PKn siswa pada sisi kognitif.

\section{Hasil dan Pembahasan}

Dari hasil perhitungan diketahui bahwa sebaran data gain skor ternormalisasi pada kedua kelompok berdistribus normal dan memiliki varians yang homogen. Setelah menganalisis data kompetensi pengetahuan PKn diperoleh rata-rata gain skor ternormalisasi pada kedua kelas yaitu pada kelompok eksperimen 0,543 dan pada kelompok kontrol 0,422. Data tersebut di bandingkan dengan Klasifikasi interpretasi gain skor ternormalisasi yakni dalam predikat cukup. Dari hasil analisis uji-t diperoleh $t_{\text {hitung }}=2,295$. Hasil tersebut kemudian dibandingkan dengan 
$t_{\text {tabel }}$ dengan $\mathrm{dk}=(42+34)-2=74$ dengan taraf signifikansi $5 \%$ sehingga diperoleh $t_{\text {tabal }}=$ 2,000, sehingga $t_{\text {hitung }}>t_{\text {tabel }}, 2,295>2,000$ maka $H_{0}$ ditolak. Hal ini berarti terdapat perbedaan yang signifikan kompetensi pengetahuan PKn kelompok siswa yang dibelajarkan menggunakan model pembelajaran jigsaw berbasis penilaian portofolio dan kelompok siswa yang dibelajarkan menggunakan pembelajaran konvensional pada kelas IV SD Gugus Teuku Umar Denpasar Barat tahun pelajaran 2017/2018. Karena terdapat perbedaan yang signifikan, maka hal tersebut berarti terdapat pengaruh model pembelajaran jigsaw berbasis penilaian portofolio terhadap kompetensi pengetahuan PKn pada siswa kelas IV SD Gugus Teuku Umar Denpasar Barat tahun Pelajaran 2017/2018.

Dengan demikian, model pembelajaran jigsaw berbasis penilaian portofolio dapat direkomendasikan dalam membelajarkan siswa khususnya pada kegiatan pembelajaran yang berisi muatan materi PKn. Pembelajaran tematik pada muatan materi PKn pada kelompok yang dibelajarkan melalui model pembelajaran jigsaw berbasis penilaian portofolio berjalan dengan baik dan kondusif. Hal tersebut dikarenakan oleh dalam proses pembelajaran siswa siswa tidak hanya berinteraksi siswa dengan guru. Akan tetapi mereka juga melakukan interaksi siswa dengan siswa lain dalam kelompok yang berbeda. Dengan demikian, siswa tidak hanya berkelompok dengan siswa yang diinginkan, tetapi siswa secara merata berkelompok dengan siswa yang lainnya, dengan diberikannya nomor dada pada setiap siswa serta pembentukan 2 kelompok yaitu kelompok asal dan kelompok ahli, kelompok asal beranggotakan siswa dengan nomor dada berbeda, dan kelompok ahli beranggotakan siswa dengan nomor dada yang sama.

Model ini juga memberikan pengalaman kepada siswa untuk mengembangkan keterampilan menyimpulkan isi berita atau informasi yang mereka peroleh dalam konteks nyata dan menjelaskan kembali informasi tersebut kepada anggota kelompok lain. Selain itu proses pembelajaran menjadi bertambah kondusif karena dipadukan dengan penilaian portofolio sehingga dapat membantu guru memantau perkembangan kompetensi pengetahuan siswa dalam pembelajaran. Hal tersebut dapat menimbulkan dan meningkatkan rasa semangat siswa dalam mengikuti pembelajaran. Berbeda pada kelompok kontrol, dengan pembelajaran konvensional sebagaimana biasa diterapkan pada kelompok kontrol. Hal ini disebabkan siswa yang kurang diberikan peranan dalam proses pembelajaran karena segala sesuatunya lebih banyak mendominasi pada guru sehingga siswa masih susah mengingat dan memahami sesuatu yang mereka terima, karena mereka tidak mengalaminya dan tidak berperan didalamnya. Dengan demikian, pembelajaran menggunakan model pembelajaran jigsaw berbasis penilaian portofolio pada penelitian ini memiliki keunggulan, yaitu melatih kesiapan siswa dalam menjawab pertanyaan yang diterima, saling memberikan pengetahuan antar siswa, dan siswa tidak merasa bosan karena mereka belajar dengan anggota kelompok yang berbedabeda. Sehingga siswa dapat lebih aktif dan mau berpartisipasi dalam pembelajaran.

Hasil temuan pada penelitian ini memiliki persamaan dengan penelitian sebelumnya yang relevan dan memperkuat hasil penelitian yang diperoleh. Hal tersebut didukung hasil penelitian yang diajukan oleh Darmada(2013) yang mengungkapkan bahwa dapat membantu siswa dalam memaksimalkan kondisi belajar untuk mencapai tujuan belajar yang maksimal. Baik pengalaman individu maupun pengalaman kelompok. Begitu pula dengan penilaian portofolio Suseni (2016) mengungkapkan bahwa pembelajaran menggunakan penilaian portofolio dapat menggambarkan kemajuan siswa dalam kurun waktu tertentu, mengetahui bagian-bagian yang perlu diperbaiki dan membangkitkan kepercayaan diri dan motivasi untuk belajar serta mendorong tanggung jawab siswa untuk belajar.

Berdasarkan uraian tersebut kelebihan pembelajaran menggunakan model pembelajaran jigsaw berbasis penilaian portofolio pada muatan materi PKn pada penelitian ini memiliki keunggulan yakni dapat mengoptimalkan kemampuan berfikir dan komunikasi lisan maupun tertulis siswa dalam mengontruksikan pengetahuan yang siswa dapat dalam kelompok ahli kepada kelompok asal, serta didukung oleh peranan guru dalam pemberian pemantapan serta pengulangan materi yang dibuktikan dengan perbandingan rata-rata gainskor kompetensi pengetahuan PKn siswa. Dimana rata-rata gain skor kelompok eksperimen lebih tinggi dibandingkan nilai rata-rata kelompok kontrol.

\section{Simpulan dan Saran}

Berdasarkan pengujian hipotesis dan pembahasan dapat disimpulkan sebagai berikut Kompetensi pengetahuan PKn kelompok siswa yang dibelajarkan menggunakan model pembelajaran jigsaw berbasis penilaian portofolio pada siswa kelas IV SD Gugus teuku Umar 
Denpasar Barat tahun pelajaran 2017/2018. Diperoleh rata-rata gain skor ternormalisasi 0,543 , rata-rata tersebut kemudian dikonversikan berdasarkan klasifikasi gain skor ternormalisasi , sehingga dapat diketahui bahwa kompetensi pengetahuan PKn siswa pada kelompok eksperimen termasuk dalam kategori cukup.

Kompetensi pengetahuan PKn kelompok siswa yang dibelajarkan menggunakan pembelajaran konvensional pada siswa kelas IV SD Gugus teuku Umar Denpasar Barat tahun pelajaran 2017/2018. Diperoleh rata-rata gain skor ternormalisasi 0,422 , rata-rata tersebut kemudian dikonversikan berdasarkan klasifikasi gain skor ternormalisasi, sehingga dapat diketahui bahwa kompetensi pengetahuan PKn siswa pada kelompok kontrol termasuk dalam kategori cukup.

Terdapat perbedaan yang signifikan kompetensi pengetahuan PKn siswa yang dibelajarkan menggunakan model pembelajaran jigsaw berbasis penilaian portofolio dan kelompok siswa yang dibelajarkan menggunakan pembelajaran konvensional pada kelas IV SD Gugus Teuku Umar Denpasar Barat Tahun Pelajaran 2017/2018. Hal ini dibuktikan dengan hasil analisis uji-t diperoleh uji $\mathrm{t}_{\text {hitung }}=2,295$ pada taraf signifikansi $5 \%$ dengan $\mathrm{dk}=74$ diperoleh nilai $t_{\text {tabel }}=2,000$ sehingga $t_{\text {hitung }}=2,295>t_{\text {tabel }}=2,000$, serta rata-rata gain skor ternormalisasi kompetensi pengetahuan PKn kelompok eksperimen $\bar{X}=0.543>\bar{X}=0.422$ rata-rata gain skor kompetensi pengetahuan PKn kelompok kontrol. Sehingga dapat disimpulkan bahwa pembelajaran dengan model pembelajaran jigsaw berbasis penilaian portofolio berpengaruh terhadap kompetensi pengetahuan PKn siswa kelas IV SD Gugus Teuku Umar Denpasar Barat tahun pelajaran 2017/2018.

Berdasarkan hasil penelitian ini, maka dapat diajukan beberapa saran sebagai tindak lanjut dari penelitian ini. Saran ini diajukan kepada berbagai kalangan sebagai berikut. 1)Guru, Melalui model pembelajaran jigsaw berbasis penilaian portofolio hasil penelitian ini dapat dipakai sebagai alternatif dan masukan untuk menambah pengetahuan dan wawasan mengenai inovasi untuk muatan materi PKn.2) Kepala Sekolah Hasil penelitian ini dapat dijadikan pertimbangan dalam pengambilan kebijakan penggunaan model pembelajaran. 3) Peneliti Lain Hasil penelitian ini diharapkan dapat menjadi salah satu refrensi dalam mengembangkan penelitian selanjutnya.

\section{Daftar Pustaka}

Adimassana. 2016. Efektivitas Penerapan Model Pembelajaran Kooperatif Tipe Jigsaw Pada Mata Pelajaran Ips Sd. Jurnal Penelitian (Edisi Khusus PGSD). Volume 20, No. 2, Desember 2016, hlm. 174-181

Agung, A.A G. 2014. Buku Ajar Metodelogi Penelitian Pendidikan. Malang : Aditya Media Publishing

Arifin, Zainal. 2009. Evaluasi Pembelajaran.Bandung: Remaja Rosdakarya

Arikunto, Suharsimi. 2016. Dasa-Dasar Evaluasi Pendidikan. Jakarta: Bumi Aksara

Budiyanto, Agus Krisno. 2016. Sintaks 45 Model Pembelajaran dalam Student Centered Learning (SCL). Malang: Universitas Muhammadiyah

Darmada, Olyn Suyanti. 2013. "Pengaruh Model Pembelajaran Cooperative Learning Tipe Jigsaw Terhadap Hasil Belajar IPS Siswa Kelas IV SDN 1 Dan 2 Rendang". Universitas Pendidikan Ganesha. Tersedia Pada http://ejournal.undiksha.ac.id (Diakses tanggal 24 November 2017)

Munirah. 2015. Sistem Pendidikan Di Indonesia: Antara Keinginan Dan Realita. Jurnal Auladuna, Vol. 2 No. 2 Desember 2015: 233-245

Pradnyani, Gst Ayu Indah. 2017. "Pengaruh Model Pembelajaran Quantum Berbasis Kearifan Lokal Tat Twam Asi Terhadap Kompetensi Pengetahuan Pkn Siswa Kelas IV SD Gugus PB. Sudirman Denpasar Barat". Universitas Pendidikan Ganesha. Tersedia Pada http://ejournal.undiksha.ac.id (Diakses tanggal 31 November 2017)

Saat, Sulaiman. 2015. Faktor-Faktor Determinan Dalam Pendidikan (Studi Tentang Makna Dan Kedudukannya Dalam Pendidikan) . Jurnal Al-Ta'dib Vol. 8 No. 2, Juli-Desember 2015 
Setyosari, Punaji. 2016. Metode Penelitian Pendidikan \& Pengembangan. Jakarta: Prenadamedia

Shoimin, Aris. 2014. 68 Model Pembelajaran Inovatif dalam Kurikulum 2013. Yogyakarta: ArRuzz Media

Sudijono, Anas. 2016. Pengantar Evaluasi Pendidikan. Jakarta : Rajawali Pers

Sugiyono. 2011. Metode Penelitian Pendidikan Pendekatan Kuantitatif, Kualiatif, dan R\&D. Bandung: Alfabeta

Sugiyono. 2017. Statistika untuk Penelitian. Bandung: Alfabeta

Suprijono, Agus. 2015. Cooperatif Learning Teori \& Aplikasi PAIKEM. Yogyakarta: Pustaka Pelajar

Susanto, Ahmad. 2013. Teori Belajar \& Pembelajaran di Sekolah Dasar. Jakarta: Kencana Prenadamedia

Suprihatin, Siti. 2015. Penggaruh Model Pembelajaran Jigsaw Terhadap Hasil Belajar Studi Masyarakat Indonesia Mahasiswa . Jurnal Pendidikan Ekonomi UM Metro.

Sutoyo. 2011. Pendidikan Kewarganegaraan untuk Perguruan Tinggi. Yogyakarta: Graha Ilmu.

Trianto. 2007. Model-model Pembelajaran Inovativ Berorientasi konstruktivistik. Jakarta:Prestasi Pustaka.

Wahyudin, Dinn, dkk. 2004. Materi Pokok Pengantar Pendidikan Jakarta: Universitas Terbuka.

Yusuf, Muri. 2015. Assesment dan Evaluasi Pendidikan. Jakarta: Kencana Prenad 